\title{
Evaluative and skin-conductance responses to Renaissance and 20th-century paintings
}

\author{
DIANNE N. SARGENT-POLLOCK and VLADIMIR J. KONEČNI \\ University of California, San Diego, La Jolla, California 92093
}

\begin{abstract}
Normative data on paintings from two periods are reported. Subjects rated the pleasingness and interestingness of 60 Renaissance and 6020 th-century (abstract) works, and indicated how much they wished to own a reproduction of each painting. Skin-conductance changes elicited by the paintings were also assessed. The data may facilitate the inclusion of real works of art in future experiments involving visual aesthetic materials (on either the independent- or the dependent-variable side) and are relevant for the research on some motivational and cognitive issues of current interest in the psychology of art.
\end{abstract}

Two major experimental approaches to the psychological study of aesthetic phenomena have been labeled "synthetic" and "analytic" (e.g., Berlyne, 1974). The synthetic method involves attempts to extract the basic elements of an artistic medium, style, or period and to develop stimulus materials from these elements. In contrast, in the analytic approach, "real" works of art are typically used as stimuli. There are, of course, advantages and disadvantages to each of these methods (see Berlyne, 1971). Both have been used at least since the time of Fechner and have played a prominent role in the recent wave of research interest in the psychology of art (e.g., Berlyne \& Ogilvie, 1974; Crozier, 1974; Cupchik, 1974; Konečni, in press; Konečni, Crozier, \& Doob, 1976; Konečni \& Sargent-Pollock, 1976, 1977; Steck \& Machotka, 1975).

The usefulness of the analytic approach depends in large part on research efforts aimed at isolating manageable subsets from the universe of artistic works and specifying the properties of the subsets and their members. In the present research, 60 Renaissance and 60 20th-century abstract paintings were used as stimuli. These two periods were chosen for their intrinsic historical interest and temporal separation, and because they are generally thought to differ on dimensions that may be labeled "orderliness," "balance," and "structuredness." Since the main purpose of the research was to obtain normative data on a relatively large number of works from each of the two periods, it was not necessary to formalize and objectify the procedure through which the paintings were chosen for inclusion in the study. The exact degree to which the two groups of paintings are representative of the Renaissance and 20th-century (abstract) styles, respectively,

This research was supported by Grant GS 42802 from the National Science Foundation to Vladimir J. Konečni. The authors wish to thank Robert B. Allen for assistance with data processing. Requests for reprints should be sent to Dianne N. Sargent-Pollock, Department of Psychology, C-009, University of California at San Diego, La Jolla, California 92093. is therefore unknown. Nonetheless, the number of works selected from each period seemed large enough to permit at least tentative between-period comparisons. Such comparisons were not possible in an otherwise very comprehensive earlier investigation by Berlyne and Ogilvie (1974).

Subjects rated the pleasingness and interestingness of each of the 120 paintings. These two evaluative dimensions were chosen because of their theoretical interest (e.g., Berlyne, 1971) and frequent use in recent psychoaesthetic research (e.g., Crozier, 1974; Day, 1967; Normore, 1974). In addition to these standard rating dimensions, a "behavioroid" measure (Aronson \& Carlsmith, 1968) was also included: Subjects indicated how much they would like to own a reproduction of each painting. Finally, because of the rising interest in the motivational aspects of art appreciation (cf. Berlyne, 1971; Child, 1969; Konečni \& Sargent-Pollock, 1977), an index of the effect of paintings on the level of physiological arousal was obtained by measuring the skinconductance changes elicited by each painting.

\section{METHOD}

\section{Subjects}

Twelve female students from the University of California at San Diego acted as subjects and were remunerated for their participation. Art majors were excluded, because a strong background in the arts has been shown to affect responses to aesthetic stimuli in a systematic manner (Crozier, 1974).

\section{Slides and Apparatus}

Sixty works, painted in the period from 1440 to 1570 , were selected because their orderly and harmonious features seemed (to the authors) to capture the essence of the Renaissance idiom. ${ }^{1}$ Sixty 20 th-century "abstract" works, painted in the period from 1909 to 1965 , were chosen for their generally nonrepresentational, surprising, and in some cases incongruous characteristics. The paintings were randomly assigned to groups of 20 and to positions within these groups, with the constraint that the works from the two periods alternate in each group. The order of the six groups was also randomly determined. All subjects saw the 120 paintings (listed in Table 1 ) in exactly the same order that had been specified by the procedures described above. 
Slides were made from color reproductions of the paintings (see Table 1 for the sources) and were projected by a Kodak Carousel $760 \mathrm{H}$ projector with automatic focus onto the wall $1.52 \mathrm{~m}$ in front of the seated subject. The projected image was approximately $46 \times 66 \mathrm{~cm}$, subtending a visual angle of 23 deg $23 \mathrm{~min}$.

Skin response was recorded by a Fels dermohmeter (automatic range set, subject current of 70 microA) and Grass pen recorder. Silver-silver chloride cup electrodes filled with the Hewlett-Packard Redux electroly tic paste were attached to the right leg of each subject. The active site was on the inside of the ankle, just forward of the Achilles tendon. The reference electrode was placed on the calf of the same leg at the fullest point.

\section{Procedure}

The subject was comfortably seated in a dimly illuminated $\left(7.8\right.$ candela $\left./ \mathrm{m}^{2}\right)$ room $(1.71 \times 1.92 \mathrm{~m})$. Throughout the course of the experiment, the subject wore headphones and had electrodes attached to her leg. ${ }^{2}$ The experimenter operated all equipment from the adjoining control room.

The study was described to the subject as dealing with "visual preferences." After an initial period of $7 \mathrm{~min}$, which allowed the skin response tracing to stabilize, the first viewing cycle began. A signal light alerted the subject when the first slide was about to appear; when the light went off, the first slide appeared. After $10 \mathrm{sec}$ of slide exposure, the light came on again, indicating that the subject should begin to make the three written ratings. At the end of that 10 -sec period, the light and slide went off simultaneously and the second slide appeared. This sequence, which consisted of $10 \mathrm{sec}$ of viewing, followed by $10 \mathrm{sec}$ of rating in the presence of the slide, was repeated until all 20 slides were shown. At the end of a cycle of 20 slides, the subject took a 3-min stretch break. Each subject had six viewing cycles of 20 slides each; thus, 120 slides were rated.

\section{Dependent Measures}

Subjects evaluated each painting on three $100-\mathrm{mm}$ continuous scales anchored as follows: Pleasing/not pleasing, interesting/not interesting, and would like/would not like (to own a reproduction). These terms were not further defined. The subjects were briefly instructed in the use of the scales, but there were no practice trials. Two subjects were randomly assigned to each of the six possible orders of presentation of the three scales; the right/left response bias was controlled by a counterbalancing procedure.

The effect of paintings on a subject's skin conductance was estimated by computing the following ratio for each work: The reading (in micromhos) at $8.5 \mathrm{sec}$ after the slide onset was divided by the mean of the readings during the $5-\mathrm{min}$ baseline period preceding the relevant group of 20 slides. $^{3}$

\section{RESULTS AND DISCUSSION}

In Table 1, the 60 Renaissance and 60 20th-century paintings are listed in groups of 20 , in the order in which they were shown to subjects. For each of the 120 paintings, the means for the three evaluative scales and the mean of the exposure/baseline skin-conductance ratios are presented. All means are based on $n=12$. The Renaissance paintings were judged to be far more pleasing, as well as more interesting, than the 20thcentury works; in addition, subjects greatly preferred to own reproductions of the Renaissance paintings. On the $10-\mathrm{cm}$ pleasingness scale, $M=5.67 \mathrm{~cm}$ for the Renaissance paintings, $M=4.23 \mathrm{~cm}$ for the 20 th-century paintings, and $t(118)=8.10, p<.01$. On the interest- ingness scale, $M=6.04$ for Renaissance, $M=5.20$ for the 20 th century, and $t(118)=5.15, p<.01$. For the wish-to-own scale, $M=4.62$ for Renaissance, $M=3.64$ for the 20th century, and $t(118)=5.41, p<.01$. Paint . ings from the two periods did not differ in their effects on skin conductance: $M=1.03$ for Renaissance, $M=1.02$ for the 20th century.

Table 2 shows intercorrelations of the four dependent measures for the Renaissance and 20th-century sets considered separately, as well as for all 120 paintings. The correlations between the three verbal measures were all positive and relatively high for the paintings from the two periods considered separately and for the entire set. However, the correlation between pleasing. ness and interestingness was much higher for the 20th. century paintings. This suggests that the frequently made assertions concerning the need to draw a sharp distinction between pleasingness and interestingness on theoretical grounds may be more justified for some than for other aesthetic materials (even within the same artistic medium). The overall correlation between pleasingness and interestingness was higher $(r=.69)$ than those obtained by Berlyne and Ogilvie (1974) for two sets of 22 paintings each ( $r s=.35$ and .37 , respectively), where both sets contained at least some paintings from each of a total of six centuries (15th-20th).

Skin conductance was essentially uncorrelated with verbal ratings (see Table 2); the pleasingness ratings of the Renaissance works provided a minor exception to this pattern $(\mathrm{r}=.25, \mathrm{p}<.06)$.

In the case of both Renaissance and 20th-century works, paintings shown early in the session had a much greater impact on skin conductance than those shown later. For both periods, the mean exposure/baseline ratios initially approached 1.20 , then rapidly declined to $1.00-1.05$, and stabilized at close to 1.00 for the remainder of the session. Whereas the tonic level of conductance gradually decreased as subjects became more and more relaxed during the course of the session (which was reflected in the diminishing baseline values for the successive groups of 20 paintings), the effect on arousal produced by the paintings decreased at an even faster rate. Presumably, after being exposed to a number of works, subjects failed to find the visual experience as arousing and exciting as they had done at the beginning of the session. This "habituation" effect was largely absent in the case of all three evaluative scales.

In conclusion, the present research provided a considerable range of responses on several dimensions of interest to a relatively large number of paintings from two radically different periods. The data we report may facilitate the inclusion of "real" works of art in experiments concerned with visual aesthetic stimuli on either the independent- or the dependent-variable side and thus be of interest to researchers who pursue the analy tic approach in the psychology of art. For example, choice between, and preference for, paintings (as opposed to various "synthesized" materials) can serve as a de- 
Table 1

Mean Evaluative and Skin-Conductance Responses to Renaissance and 20th-Century Paintings

\begin{tabular}{lcc} 
Painting & $\begin{array}{c}\text { Pleasing- } \\
\text { ness }\end{array}$ & $\begin{array}{c}\text { Interest- } \\
\text { ingness }\end{array} \begin{array}{c}\text { Wish to } \\
\text { Own }\end{array} \begin{array}{c}\text { Skin Con- } \\
\text { ductance }\end{array}$ \\
\hline
\end{tabular}

Renaissance Paintings: Group 1

Michelangelo, "The Holy Family," 1503 (4)

Raphael, "Vision of a Knight," 1500 (7)

Da Vinci, "The Baptism of Christ," c. 1477 (5)

Perugino, "Madonna and Child With Sts. Catherine and Joseph," c. 1495 (1)

Raphael, "Baldassari Castiglione," 1516 (1)

Da Vinci, "Madonna and Child With St. Anne,"* c. 1510 (1)

Michelangelo, "Flood" (detail: Sistine Ceiling), c. 1510 (4)

Carpeccio, "St. Stephen Preaching," c. 1516 (1)

Raphael, "Marriage of the Virgin," 1504 (7)

Da Vinci, "Madonna With a Carnation," 1478 (5)
20th-Century Paintings: Group 1

\section{$6.12(2.20)$}

$5.00(2.21)$

$7.12(2.08)$

$7.12(2.08)$

$7.12(1.92)$

$5.75(2.26)$

$5.04(2.53)$

$5.62(2.50)$

$5.50 \quad(2.44)$

$6.08(2.00)$

$3.79(2.88)$

$5.21(2.90)$

$3.42(2.83)$

$3.04 \quad(2.22)$

$4.25 \quad(3.18)$

3.17 (2.42)

$2.54(2.77)$

$3.00(2.21)$

$5.46(2.96)$

\section{$6.20(2.60)$}

$5.25(2.50)$

$5.67(3.30)$

$6.58(2.34)$

$6.12(2.51)$

$5.42(2.13)$

7.04 (1.76)

$6.29(2.50)$

$6.83(1.91)$

$5.67(2.44)$

$4.71(3.70)$

5.88 (3.13)

$6.38(2.33)$

$4.92(3.25)$

4.50 (3.44)

$4.75(2.52)$

$4.71(2.74)$

$3.08 \quad(3.12)$

$4.67(3.09)$

$6.17(2.89)$

5.04 (2.73)

$5.88(2.94)$

$6.33(2.42)$

$7.25(1.76)$

$6.29(2.68)$

$5.29(2.92)$

$5.25 \quad(2.78)$

$6.50(2.14)$

$6.67(2.82)$

$5.88(2.47)$
$4.79(3.00)$

3.67 (3.05)

5.67 (2.77)

$5.00(3.29)$

$5.79(3.22)$

4.38 (3.15)

$5.38(2.73)$

$4.67(3.10)$

4.67 (3.08)

$4.79(2.76)$

$3.29(3.60)$

3.17 (2.73)

$4.50(2.84)$

$3.38(2.96)$

2.25 (2.73)

$4.04(3.23)$

$2.96(2.86)$

$1.67(1.98)$

$1.50(1.91)$

$4.92(2.87)$
$1.18(.35)$

$1.19(.35)$

$1.19(.31)$

$1.13(.26)$

$1.10(.25)$

$1.08(.25)$

$1.06(.24)$

$1.04(.26)$

$1.04(.27)$

$1.04(.27)$
Kandinsky, "First Abstract Watercolor," 1910 (9)

Léger, "The Card Game," 1917 (8)

Kandinsky, "Painting of All Saints Day," 1911 (9)

Piper, "Painting," 1935 (8)

Masson, "The Ghouls," 1961 (8)

Gorky, "Agony," 1947 (8)

Kandinsky, "Saint George I," 1911 (9)

De Kooning, "Door to the River," c. 1950 (8)

Pollock, "Painting," 1945 (8)

Tobey, "Capricorn," 1957 (8)

$3.67(2.92)$

Renaissance Paintings: Group 2

Michelangelo, "Fall" (detail: Sistine Ceiling), c. 1510 (4)

Raphael, "Madonna of the Goldfinch," 1505 (7)

Da Vinci, "The Annunciation" (detail: angel), c. 1480 (5)

Titian, "Man With a Glove," c. 1510 (1)

Raphael, "Madonna," c. 1510 (3)

Da Vinci, "Bacchus," c. 1510 (1)

Michelangelo, "Delphic Sy bil"' (detail: Sistine Ceiling), c. 1510 (4)

Titian, "Alphonso of Ferrara and Laura Dianti," c. 1520 (1)

Raphael, "Madonna of the Meadows," 1506 (7)

Da Vinci, "The Annunciation" (detail: Virgin), c. 1480 (5)
$6.38(2.81)$

$5.62(2.87)$

$6.33(2.72)$

$6.42(2.32)$

$5.88(2.38)$

$5.42(2.99)$

$4.88(3.08)$

$5.83(2.96)$

$5.79(3.06)$

$5.29(3.41)$

\section{0th-Century Paintings: Group 2}

Francis, "Composition," 1957 (8)

Léger, "Wheels and the City," 1919 (8)

Kandinsky, "The Flood," 1912 (9)

Picasso, "Seated Woman," 1909 (2)

Duchamp, "Nude Descending a Staircase," 1912 (2)

Klee, "The Harbor of Hammamet," 1914 (6)

Kandinsky, "Improvisation 30," 1913 (9)

Miro, "Maternity," 1924 (2)

Delauney, "Hommage to Berliot," 1914 (6)

Kandinsky, "Improvisation 'Klamm'," 1914 (9)

Renaissance Paintings: Group 3

Michelangelo, "Prophet Ezekiel" (detail: Sistine Ceiling), c. 1510 (4)

Da Vinci, "Virgin of the Rock,"** 1483 (5)

Raphael, "Portrait of Agnolo Doni," 1505 (7)

Titian, "Madonna With a Rabbit," c. 1510 (1)

Raphael, "The Beautiful Jardinière," c. 1507 (1)

Da Vinci, "St. John the Baptist," c. 1480 (1)

Veronese, "Crucifixion," 1570 (1)

Raphael, "St. Catherine of Alexandria," 1508 (7)

Carravaggio, "Death of the Virgin," c. 1600 (1)

Da Vinci, "Portrait of the Lady With the Ermine," 1485 (5)

20th-Century Paintings: Group 3

$3.83(2.22)$

$4.29(2.41)$

$4.04(3.09)$

$5.67(2.61)$

$5.67(2.23)$

$5.75(2.71)$

$4.08 \quad(3.37)$

$4.75(2.86)$

$5.96(2.82)$

4.67 (2.67)

$4.71(2.54)$

$5.04(2.99)$

$4.54(3.17)$

$6.04(2.76)$

$5.79(2.80)$

$5.83(2.76)$

$5.42(3.06)$

$7.92(2.40)$

$6.12(2.32)$

$6.12(3.09)$

4.79 (2.73)

$4.42(2.90)$

$5.96(3.19)$

$6.12(2.23)$

$4.75(3.05)$

4.58 (3.06)

$4.04(3.25)$

$5.50(2.99)$

$5.00(3.42)$

$4.00(2.88)$

$2.42(2.18)$

5.68 (2.89)

$3.33(2.75)$

5.25 (3.60)

4.83 (3.46)

4.42 (2.92)

3.50 (3.35)

$3.63(2.99)$

$5.42(3.05)$

$3.46(2.40)$

$4.96 \quad(2.23)$

$7.33(1.60)$

$5.25 \quad(2.64)$

$6.42(2.15)$

$6.38(2.66)$

$4.71(3.01)$

$5.79(2.81)$

$5.75(2.68)$

$4.08(2.85)$

7.12 (1.77)

5.62 (2.55)

4.92 (3.02)

.

$5.46(2.55)$

$5.33(2.60)$

$4.50(2.66)$

3.96 (3.09)

3.33 (2.98)

5.04 (2.38)

$4.33(2.72)$

$5.17(3.21)$

$5.08(2.65)$

$6.12(2.90)$

$4.79(2.70)$

3.21 (3.12)

3.96 (2.87)

$6.17(2.40)$

$6.58(3.00)$

$4.08(2.82)$

4.58 (3.33)

$1.19(.40)$

$1.18(.33)$

$1.14(.29)$

$1.11(.24)$

$1.10(.23)$

$1.07(.24)$

$1.06(.26)$

$1.04(.26)$

$1.04(.27)$

$1.05(.29)$

$1.06(.06)$

$1.05(.06)$

$1.06(.06)$

$1.06(.05)$

$1.05(.05)$

$1.05(.06)$

$1.05(.07)$

$1.06(.06)$

$1.08 \quad(.06)$

$1.08(.05)$

$1.06(.09)$

$1.04(.06)$

$1.07(.07)$

$1.05(.05)$

$1.06(.04)$

$1.04(.07)$

$1.05(.07)$

$1.05(.06)$

$1.06(.07)$

$1.08(.07)$

$1.01(.07)$

$1.00(.07)$

$1.01 \quad(.06)$

$1.00(.07)$

$.99(.08)$

$1.00(.08)$

$1.00(.10)$

$1.00(.10)$

$1.00(.10)$

$1.00(.10)$
Braque, "The Guitarist," 1914 (8)

Kandinsky, "Painting With Three Spots," 1914 (9)

De Staël, "Footballers," 1952 (8)

Wols, "Detail from a Painting," 1948 (8)
$6.46(2.86)$

$4.62(2.57)$

3.96 (3.14)

3.12 (2.81)
$6.92(2.56)$

$4.96(2.88)$

4.79 (3.17)

4.46 (3.35) 
Table 1 Continued

\begin{tabular}{|c|c|c|c|c|}
\hline Painting & $\begin{array}{l}\text { Pleasing- } \\
\text { ness }\end{array}$ & $\begin{array}{l}\text { Interest- } \\
\text { ingness }\end{array}$ & $\begin{array}{l}\text { Wish to } \\
\text { Own }\end{array}$ & $\begin{array}{l}\text { Skin Con- } \\
\text { ductance }\end{array}$ \\
\hline $\begin{array}{l}\text { Kandinsky, "Painting With Highlighted Background," } 1916 \text { (9) } \\
\text { Delauney, "Window," } 1912(8) \\
\text { Pollock, "No. 6," } 1945(8) \\
\text { Kandinsky, "In the Black Circle," } 1923(9) \\
\text { Picabia, "Young American Girl," } 1913(8) \\
\text { Tobey, "Messengers," } 1965 \text { (8) }\end{array}$ & $\begin{array}{ll}3.88 & (2.99) \\
4.38 & (3.15) \\
4.12 & (2.96) \\
4.42 & (2.88) \\
5.12 & (2.56) \\
3.29 & (2.26)\end{array}$ & $\begin{array}{l}4.25(2.65) \\
3.50(2.69) \\
5.04(2.80) \\
5.79(2.84) \\
6.00(2.66) \\
4.08(2.60)\end{array}$ & $\begin{array}{ll}3.79 & (3.09) \\
3.67 & (3.22) \\
3.08 & (2.66) \\
3.36 & (3.06) \\
4.67 & (2.72) \\
2.54 & (2.16)\end{array}$ & $\begin{array}{r}.98(.10) \\
1.00(.09) \\
.99(.11) \\
1.00(.10) \\
1.00(.10) \\
1.00(.11)\end{array}$ \\
\hline
\end{tabular}

Renaissance Paintings: Group 4

Michelangelo, "Prophet Jeremiah" (detail:

Da Vinci, "Virgin of the Rock,"** 1503 (5)

Tiepolo, "Last Supper," 1753 (1)

Guardi, "The Doge Embarking on the Bucentaur," c. 1750 (1)

Raphael, "The Veiled Lady," 1513 (7)

Da Vinci, "Madonna and Child With St. Anne,"* 1510 (5)

Titian, "Cardinal Perronot de Granvilla," c. 1530 (3)

Michelangelo, "Virgin and Child With St. John and Four Angels," 1500 (3)

Raphael, "Madonna of the Chair," 1514 (7)

Kandinsky, "Little Red Dream," 1925 (9)

Picasso, "My Pretty One," 1911 (2)

Léger, "The Wedding," 1912 (2)

Boccioni, "The Forces of the Street," 1911 (6)

Kandinsky, "Several Circles," 1926 (9)

Marc, "Lightning Forms," 1914 (2)

Boccioni, "The City Rises," 1910 (2)

Kandinsky, "Soft Structure," 1927 (9)

Carra, "The Milan Galeria," 1912 (6)

Kandinsky, "Black Lines," 1913 (2)
20th-Century Paintings: Group 4

5.17 (2.58)

$3.54(2.57)$

$5.46(2.39)$

$5.92(1.77)$

$4.62(3.30)$

$4.25(3.18)$

$4.00(2.46)$

$6.38(3.26)$

$4.04(2.51)$

$5.08(2.88)$

Renaissance Paintings: Group 5

Michelangelo, "Last Judgment" (detail: the Blessed), 1537 (4)

Raphael, "Portrait of Bindo Altoviti," 1515 (7)

Da Vinci, "The Beautiful Ferronnière," 1490 (5)

Botticelli, "Madonna and Child With St. John," c. 1480 (1)

Tintoretto, "Miracle of St. Mark," c. 1555 (3)

Michelangelo, "Last Judgment" (detail: the Saints), 1537 (4)

Da Vinci, "Portrait of a Lady," 1490 (5)

Raphael, "Madonna of the Fish," 1515 (7)

Tiepolo, "The Minuet," c. 1740 (1)

Raphael, "The Fire in the Borgo," 1514 (7)

Severini, "Dynamism of a Dancer," 1913 (6)

Kandinsky, "Black Shapes on White," 1934 (9)

Villon, "Soldiers Marching," c. 1910 (6)

Boccioni, "Elasticity," 1912 (2)

Kandinsky, "Additional Brown," 1935 (9)

Léger, "Contrast of Forms," 1913 (6)

Picasso, "Three Musicians," 1921 (2)

Gris, "Still Life in Front of an Open Window," 1915 (2)

Kandinsky, "Dominant Curve," 1936 (9)

Picasso, "The School Girl," 1919 (6)

Michelangelo, "Crucifixion of St. Peter," 1550 (4)

Botticelli, "Madonna and Child," c. 1480 (1)

Raphael, "Portrait of Leo X and Two Cardinals," 1517 (7)

Van Cleve, "Madonna With the Carnation," c. 1520 (3)

Murillo, "Madonna and Child," c. 1650 (3)

Da Vinci, "Portrait of a Musician," 1490 (5)

Giorgioni, "Pastoral Concert," c. 1500 (1)

Raphael, "The Vision of Ezekiel," 1518 (7)

Bellini, "Madonna and Child With Donor," c. 1450 (1)

Lippi, "Madonna With Child and Saints," c. 1440 (1)
Renaissance Paintings: Group 6

$4.42(1.92)$

$5.71(2.69)$

$6.29(2.92)$

$6.38(1.76)$

$4.17(2.46)$

$5.04(1.79)$

$6.71(2.70)$

$6.33(2.19)$

$6.71(1.86)$

$4.67(2.34)$

20th-Century Paintings: Group 5

$3.33(2.47)$

$4.21(3.14)$

$4.46 \quad(2.73)$

$4.25 \quad(2.32)$

$3.83(2.60)$

$2.83(1.84)$

$5.46(3.23)$

$4.42(2.52)$

$3.96(2.69)$

$2.75(2.06)$

4.08 (2.62)

$5.50 \quad(2.16)$

4.75 (1.95)

$5.62(2.55)$

6.04 (1.89)

$4.96(2.95)$

4.96 (2.73)

$7.54(2.16)$

4.67 (2.61)

$5.96(1.88)$
$5.25(2.77)$

4.83 (3.02)

$4.21(3.09)$

4.21 (3.29)

$5.92(2.56)$

$7.38(1.71)$

$6.54(2.62)$

4.12 (2.45)

6.38 (2.09)

4.50 (2.33)

$6.54(2.15)$

5.75 (2.22)

$5.79(2.37)$

3.96 (2.69)

$5.00(2.79) \quad 4.00(2.80)$

$7.12(2.10) \quad 3.71(2.94)$

$5.79(2.58) \quad 5.67(2.77)$

$1.02(.07)$

$.99(.10)$

$1.00(.10)$

$1.00(.11)$

$1.01(.12)$

$1.01(.10)$

$1.00(.12)$

$1.00(.14)$

$1.00(.12)$

$1.01(.13)$

5.88 (2.99) $4.42(2.83)$ $4.42(2.56) \quad 3.62(2.61)$

$7.67(2.18) \quad 5.84(2.47)$

$6.67(2.05) \quad 5.33(2.16)$

$5.00(2.43) \quad 3.67(2.27)$

$5.46(2.36) \quad 4.46(2.97)$

$7.17(1.71) \quad 3.67(2.89)$

$6.71(2.72) \quad 6.08(3.64)$

$5.25(2.89) \quad 3.12(3.22)$

$5.42(2.91)$

$4.38(3.19)$

$1.01(.06)$

$1.01(.07)$

$1.00(.09)$

$1.00(.10)$

$1.01(.12)$

$1.00(.13)$

$.99(.14)$

$.99(.13)$

$1.01(.11)$

$1.00(.13)$

$6.00(1.83) \quad 3.50(1.97)$

$5.67(2.89)$

$4.62(3.50)$

$6.67(2.57) \quad 4.92(3.15)$

$6.17(2.18)$

$4.92(2.04)$

6.29 (2.12) 3.33 (2.61)

$5.96(2.39) \quad 4.29(2.39)$

$6.50(2.50) \quad 5.96(3.15)$

$6.08(2.70) \quad 4.62$ (2.64)

$6.46(2.09) \quad 5.71 \quad(2.45)$

$7.00(1.70) \quad 5.08(2.75)$

$1.01(.04)$

$1.02(.03)$

$1.02(.04)$

$1.00(.04)$

$1.00(.06)$

$.99(.08)$

$.97(.09)$

$.98(.11)$

$.97(.12)$

$.98(.11)$

$5.17(3.43) \quad 2.58(2.57)$

$4.92(2.80) \quad 3.12(3.05)$

$1.03(.06)$

$5.75(2.58)$

$4.00(2.71)$

$5.33(2.07) \quad 3.33(2.38)$

$4.00(2.80) \quad 2.83(2.54)$

$3.62(2.92) \quad 2.00(2.68)$

6.58 (3.11) $4.75(3.22)$

$5.96(2.78) \quad 4.33(3.32)$

$4.92(3.38) \quad 2.67(2.73)$

$4.29(2.97) \quad 3.17(2.43)$

$.93(.29)$

$1.02(.05)$

$1.00(.03)$

$.98(.07)$

$.98(.09)$

$.98(.10)$

$.98(.12)$

$.97(.12)$

$.97(.12)$

$4.50(2.51) \quad 2.58(2.20)$ $6.04(2.43) \quad 3.71(2.02)$

$6.17(2.23) \quad 3.92(2.09)$

$5.88(2.81) \quad 4.96(2.62)$

$6.08(2.12) \quad 5.21 \quad(2.29)$

$6.29(3.15) \quad 4.04(2.95)$

5.54 (2.87) $3.75(2.88)$

$7.88(1.82) \quad 6.79(2.81)$

$\begin{array}{llll}5.71(2.93) & 2.58(2.73)\end{array}$

$6.88(1.85) 4.50(2.64)$
$1.00(.04)$

$.99(.06)$

$.99(.07)$

$.98(.09)$

$1.00(.08)$

$.99(.09)$

$.98(.10)$

$1.00(.11)$

$1.00(.11)$
$.99(.09)$ 
Table 1 Continued

\begin{tabular}{|c|c|c|c|c|}
\hline Painting & $\begin{array}{l}\text { Pleasing- } \\
\text { ness }\end{array}$ & $\begin{array}{l}\text { Interest- } \\
\text { ingness }\end{array}$ & $\begin{array}{l}\text { Wish to } \\
\text { Own }\end{array}$ & $\begin{array}{l}\text { Skin Con- } \\
\text { ductance }\end{array}$ \\
\hline \multicolumn{5}{|c|}{ 20th-Century Paintings: Group 6} \\
\hline Kandinsky, "Fixed Points," 1929 (9) & $4.96(2.62)$ & $5.46(2.58)$ & $4.29(3.48)$ & $1.00(.03)$ \\
\hline Kandinsky, "Composition X," 1939 (9) & $3.50(2.94)$ & $4.46(3.28)$ & $2.96(2.41)$ & $1.00(.05)$ \\
\hline Villon, "Farm Yard With Pigeon House," c. 1910 (6) & $2.38(1.54)$ & $2.54(3.17)$ & $1.54(5.56)$ & $.99(.06)$ \\
\hline Kandinsky, "Varied Actions," 1941 (9) & $3.25(2.86)$ & $3.92(3.04)$ & $2.71(2.39)$ & $1.00(.08)$ \\
\hline Balla, "Speeding Automobile,"1912 (2) & $3.58(2.96)$ & $4.75(2.92)$ & $3.38(3.05)$ & $.99(.09)$ \\
\hline Kandinsky, "Succession," 1935 (9) & $2.88(2.26)$ & $4.12(3.77)$ & $2.42(2.01)$ & $.92(.30)$ \\
\hline Kandinsky, "Circle and Square," $1943(9)$ & $4.33(2.51)$ & $5.38(2.45)$ & $3.71(2.49)$ & $.99(.09)$ \\
\hline Boccioni, "The Charge of the Lancers," 1915 (2) & $4.50(3.17)$ & $6.00(3.15)$ & $3.58(3.82)$ & $.99(.09)$ \\
\hline Kandinsky, "White Voltage," 1944 (9) & $2.67(2.23)$ & $3.54(3.00)$ & $2.25(2.84)$ & $.99(.11)$ \\
\hline Braque, "Composition With a Violin," $1910(8)$ & $4.00(3.53)$ & $4.75(3.17)$ & $3.75(3.31)$ & $1.00(.10)$ \\
\hline
\end{tabular}

Note-Paintings are listed by period and in the order in which they were shown to subjects. The Renaissance and 20th-Century works alternated within each of the six groups of 20 paintings. In Groups 1, 3, and 5, a Renaissance painting was shown first, whereas Groups 2, 4, and 6 began with a 20th-Century work. Entries in the Pleasingness, Interestingness, and Wish to Own columns represent mean distances in centimeters $(n=12)$ from the negative ends of the $10-\mathrm{cm}$ scales (standard deviations are given in parentheses). Each entry in the Skin Conductance column is a mean $(n=12)$ of the ratios of the skin-conductance value (in micromhos) during the viewing of a slide to the baseline value for the appropriate group of 20 slides (standard deviations are in parentheses). Numbers in parentheses in the Painting column indicate the source of reproductions from which the slide of a particular painting was made. (1) Bazin, G. Louvre: Masterpieces of Italian painting. Greenwich, Conn: New York Graphic Society, 1956. (2) Copplestone, T. Modern art movements. London: Spring Books, 1962. (3) Crane, A. (Ed.), A gallery of great paintings. New York: Crown, 1944. (4) Lecaldono, P. (Ed.), The complete paintings of Michelangelo. New York: Harry N. Abrams, 1966. (5) L'opera completa di Leonardo pittore. Milan: Rizzoli, 1967. (6) Moore, G. Modern painting. New York: Boni and Liveright, 1923. (7) Sanzio, M. (Ed.), Raphael. London: Beaverbrook, 1960. (8) Waddington, C. H. Behind appearance. Cambridge, Mass: M.I.T. Press, 1970. (9) Whitford, F. Kandinsky. Paris: O.D.E.G.E., 1968.

${ }^{*} T$ wo slides of the same painting were made (see Groups 1 and 4) from two reproductions (Sources 1 and 5 , respectively) which differed considerably in colorimetric characteristics.

${ }^{*}$ The 1483 Virgin of the Rock is in the Louvre, Paris. The 1503 version is in the National Gallery, London.

Table 2

Intercorrelations of Evaluative and Skin-Conductance Responses to Renaissance and 20th-Century Paintings

\begin{tabular}{|c|c|c|c|c|c|c|c|c|c|c|}
\hline \multirow[b]{3}{*}{$\begin{array}{c}\text { Response } \\
\text { Dimensions }\end{array}$} & & \multicolumn{9}{|c|}{ Response Dimensions } \\
\hline & & \multicolumn{3}{|c|}{ Interestingness } & \multicolumn{3}{|c|}{ Wish to Own } & \multicolumn{3}{|c|}{ Skin Conductance } \\
\hline & & $\begin{array}{l}\text { Renais- } \\
\text { sance }\end{array}$ & $\begin{array}{c}\text { 20th } \\
\text { Century }\end{array}$ & All & $\begin{array}{c}\text { Renais- } \\
\text { sance }\end{array}$ & $\begin{array}{c}\text { 20th } \\
\text { Century }\end{array}$ & All & $\begin{array}{l}\text { Renais- } \\
\text { sance }\end{array}$ & $\begin{array}{c}\text { 20th } \\
\text { Century }\end{array}$ & All \\
\hline Pleasingness & $\begin{array}{l}\text { Renaissance } \\
\text { 20th Century } \\
\text { All }\end{array}$ & $.33^{* *}$ & $.78^{*}$ & $.69 *$ & $.82^{*}$ & $.90^{*}$ & $.88^{*}$ & $.25^{* * *}$ & .06 & .15 \\
\hline Interestingness & $\begin{array}{l}\text { Renaissance } \\
\text { 20th Century } \\
\text { All }\end{array}$ & & & & $.52 *$ & $.73^{*}$ & $.72 *$ & -.15 & .15 & .05 \\
\hline Wish to Own & $\begin{array}{l}\text { Renaissance } \\
\text { 20th Century } \\
\text { All }\end{array}$ & & & & & & & .13 & .05 & .10 \\
\hline
\end{tabular}

Note-The Renaissance and 20th-Century sets contained 60 paintings each (df $=58$ for the correlations involving these sets). "All" refers to the entire set of 120 paintings (df $=118$ for the relevant correlations). $\quad{ }^{*} p<.01 \quad{ }_{* *} p<.05{ }^{* * *} p<.06$

pendent variable in experiments concerned with the effects of cognitive, motivational, and emotional processes on aesthetic appreciation (e.g., Konečni \& Sargent-Pollock, 1977). In addition, paintings varying in interestingness, pleasingness, and arousal potential can be used in the construction of independent variables designed to affect the degree of processing effort, attention, and the like (cf. Konečni \& Sargent-Pollock, 1976).

\section{REFERENCES}

Aronson, E., \& Carlsmith, J. M. Experimentation in social psychology. In G. Lindzey \& E. Aronson (Eds.), The handbook of social psychology (Vol. 2) (2nd ed.). Reading, Mass: Addison-Wesley, 1968.

Berlyne, D. E. Aesthetics and psychobiology. New York: Appleton-Century-Crofts, 1971.

BERLYNe, D. E. The new experimental aesthetics. In D. E. Berlyne (Ed.), Studies in the new experimental aesthetics. New York: Hemisphere, Wiley, 1974. 
Berlyne, D. E., \& Ogilvie, J. C. Dimensions of perceptions of paintings. In D. E. Berlyne (Ed.). Studies in the new experimental aesthetics. New York: Hemisphere, Wiley, 1974.

ChILd. I. L. Esthetics. In G. Lindzey \& E. Aronson (Eds.), The handbook of social psychology (Vol. 3) (2nd ed.). Reading, Mass: Addison-Wesley, 1969.

Crozier, J. B. Verbal and exploratory responses to sound sequences varying in uncertainty level. In D. E. Berlyne (Ed.), Studies in the new experimental aesthetics. New York: Hemisphere, Wiley, 1974.

CupCHIK, G. C. An experimental investigation of perceptual and stylistic dimensions of paintings suggested by art history. In D. E. Berlyne (Ed.). Studies in the new experimental aesthetics. New York: Hemisphere, Wiley, 1974.

DAY, H. I. Evaluation of subjective complexity, pleasingness, and interestingness, for a series of random polygons varying in complexity. Perception \& Psychophysics, 1967, 2. $281-286$.

Konećni, V. J. Quelques déterminants sociaux, émotionnels et cognitifs des préférences esthétiques relatives à des melodies de complexité variable. Proceedings of the 6th International Colloquium of Experimental Aesthetics (Paris, France, 1976), in press. (Some social, emotional, and cognitive determinants of aesthetic preference for melodies differing in complexity.)

Konećni, V. J., Crozier, J. B., \& Doob, A. N. Anger and expression of aggression: Effects on aesthetic preference. Scientific A esthetics, 1976, 1, 47-55.

Konečni, V. J., \& Sargent-Pollock, D. N. Choice between melodies differing in complexity under divided-attention conditions. Journal of Experimental Psychology: Human Perception and Performance, 1976, 2, 347-356.
Konećni, V. J., \& Sargent-Pollock, D. N. Arousal, positive and negative affect, and preference for Renaissance and 20th century paintings. Motivation and Emotion, 1977, 1, 75-93.

Normore, L. F. Verbal responses to visual sequences varying in uncertainty level. In D. E. Berlyne (Ed.), Studies in the new experimental aesthetics. New York: Hemisphere, Wiley, 1974.

Steck, L., \& MachotKa, P. Preference for musical complexity: Effect of context. Joumal of Experimental Psychology: Human Perception and Performance, 1975, 1, 170-174.

\section{NOTES}

1. Actually, five works were painted after 1570: one by Carravaggio (c. 1600), one by Guardi (c. 1750), one by Murillo (c. 1650), and two by Tiepolo (c. 1740 and 1753). These paintings were originally included in the Renaissance sample for reasons that are irrelevant to the present paper. Since many characteristics of these 5 works, as well as subjects' responses to them, were similar to those for the remaining 55 Renaissance works, the means and analyses we report are based on all 60 paintings.

2. Headphones were worn to block extraneous sounds and increase comparability with the viewing conditions in other experiments in which we used these paintings.

3 . In the research reported by Konečni and Sargent-Pollock (1977), a somewhat different procedure for computing the baseline was used, which resulted in slightly higher ratios.

(Received for publication July 6, 1976; revision accepted December 3, 1976.) 